\title{
Campylobacter jejuni induces transcytosis of commensal bacteria across the intestinal epithelium through M-like cells
}

\author{
Lisa D Kalischuk, Frances Leggett, G Douglas Inglis ${ }^{*}$
}

\begin{abstract}
Background: Recent epidemiological analyses have implicated acute Campylobacter enteritis as a factor that may incite or exacerbate inflammatory bowel disease (IBD) in susceptible individuals. We have demonstrated previously that $C$. jejuni disrupts the intestinal barrier function by rapidly inducing epithelial translocation of non-invasive commensal bacteria via a transcellular lipid raft-mediated mechanism ('transcytosis'). To further characterize this mechanism, the aim of this current study was to elucidate whether $C$. jejuni utilizes M cells to facilitate transcytosis of commensal intestinal bacteria.

Results: C. jejuni induced translocation of non-invasive E. coli across confluent Caco-2 epithelial monolayers in the absence of disrupted transepithelial electrical resistance or increased permeability to a $3 \mathrm{kDa}$ dextran probe. $C$. jejuni-infected monolayers displayed increased numbers of cells expressing the M cell-specific marker, galectin-9, reduced numbers of enterocytes that stained with the absorptive enterocyte marker, Ulex europaeus agglutinin-1, and reduced activities of enzymes typically associated with absorptive enterocytes (namely alkaline phosphatase, lactase, and sucrase). Furthermore, in Campylobacter-infected monolayers, E. coli were observed to be internalized specifically within epithelial cells displaying M-like cell characteristics.

Conclusion: These data indicate that $C$. jejuni may utilize M cells to promote transcytosis of non-invasive bacteria across the intact intestinal epithelial barrier. This mechanism may contribute to the inflammatory immune responses against commensal intestinal bacteria commonly observed in IBD patients.
\end{abstract}

\section{Background}

Inflammatory bowel diseases (IBD) are chronic $\mathrm{T}$ cellmediated diseases that are thought to result from the loss of immunologic tolerance towards commensal intestinal microorganisms [1]. Intestinal epithelial barrier dysfunction is proposed to be a primary factor contributing to IBD pathogenesis $[2,3]$. By facilitating the translocation of commensal bacteria across the intestinal barrier, dysfunction of the epithelium may enable the inappropriate activation of $\mathrm{T}$ lymphocytes that recognize and respond to constituents of the microbiota. Studies have shown that IBD patients exhibit increased rates of systemic endotoxemia [4], have higher amounts of bacterial DNA in their serum [5], and have exaggerated humoral immune responses to intestinal bacterial

\footnotetext{
*Correspondence: Douglas.Inglis@agr.gc.ca

Agriculture and Agri-Food Canada, $54031^{\text {st }}$ Avenue South, T1J 4B1, Lethbridge, $A B$, Canada
}

antigens [6-8], implying that bacterial antigens are able to translocate across the intestinal epithelium. Although several studies have observed elevated intestinal permeability ("leaky gut") and transcellular uptake of intestinal antigens in IBD patients [9-11], the mechanisms contributing to this barrier dysfunction have yet to be fully elucidated.

An increasing number of clinical studies have indicated that in some patients, IBD onset or reactivation occurs following a bout of acute bacterial enteritis [12-15]. Recently, two controlled cohort studies have implicated that enteritis incited by Campylobacter or Salmonella, which are the leading causes of bacterial enteritis in many countries, is a risk factor for subsequent development of IBD $[16,17]$. Although the mechanisms involved are unknown, pathogen-mediated intestinal epithelial barrier dysfunction may facilitate the translocation of commensal bacteria across the epithelium. In this regard, 
we have recently shown that $C$. jejuni induces translocation of non-invasive commensal bacteria across the intestinal epithelium via an uncharacterized transcellular mechanism involving lipid raft-mediated endocytosis $[18,19]$.

Microfold or M cells are specialized epithelial cells that sample antigens from the mucosal surface and transport them via a transcellular route to the basolateral membrane (herein defined as "transcytosis"). Intestinal $\mathrm{M}$ cells are primary found within the follicleassociated epithelium (FAE) of Peyer's patches and isolated lymphoid follicles, but are also occasionally found interspersed amongst the absorptive enterocytes of villar epithelium [20]. While $M$ cells are principally involved in immune surveillance of intestinal antigens, they also represent an important portal by which enteric bacteria can translocate across the intestinal barrier [21]. Studies have suggested that pathogens may exploit $M$ cell function and upregulate the rate of bacterial transcytosis by either stimulating de novo formation of $\mathrm{M}$ cells $[20,22,23]$ or increasing the rate of uptake for pre-existing $M$ cells [24]. While controversy exists with respect to which of these mechanisms is responsible for increased bacterial trafficking, it is clear that certain pathogenic microorganisms can alter $M$ cell function and increase the rate of transcytosis.

$\mathrm{M}$ cell trafficking of bacteria has been studied in vitro using polarized Caco-2 monolayers which have been stimulated to differentiate into M-like cells by co-culture with B lymphocytes [25]. Subsequent studies have shown that M-like cells capable of transporting noninvasive Vibrio cholerae are naturally present in Caco-2 monolayers despite the absence of B lymphocytes [26]. The resultant M-like cells display many of the in vivo characteristics of $\mathrm{M}$ cells including increased ability to ingest and transport exogenous particles, disorganized microvilli structure, decreased absorptive intestinal epithelial enzyme activities, reduced binding of the lectin, Ulex europaeus agglutinin-1 (UEA-1), and increased expression of the M-cell specific marker, galectin-9 [27]. We utilized Caco-2 monolayers to test the hypothesis that $C$. jejuni induces trancytosis of non-invasive commensal bacteria across the intestinal epithelium through M-like cells. Specifically, the objectives were to determine if $C$. jejuni: (1) increases transcytosis of non-invasive E. coli across polarized Caco-2 monolayers; (2) increases the abundance of M-like cells within Caco-2 monolayers; and (3) induces internalization of non-invasive $E$. coli specifically within M-like cells.

\section{Results and discussion}

Our previous findings indicate that C. jejuni 81-176 induces transcytosis of non-invasive E. coli ("commensal bacteria") across polarized human colonic T84 monolayers [18]. Since other studies have shown that certain bacteria can rapidly up-regulate $\mathrm{M}$ cell-mediated antigen transcytosis $[20,22-24,28]$, we examined whether $C$. jejuni utilizes $\mathrm{M}$-like cells to facilitate intestinal epithelial transcytosis of non-invasive bacteria. The T84 cell line has not been characterized with respect to the presence of M-like cells; thus for this current study, we used Caco-2 monolayers in which M-like cells have previously been characterized $[25,26]$ in order to assess whether $C$. jejuni 81-176 induces translocation of non-invasive $E$. coli. In agreement with our previous study using T84 monolayers, we observed that $C$. jejuni induced internalization $(\sim 1.4$-fold; $P=0.023)$ and translocation ( 7.5-fold; $P=0.023)$ of $E$. coli across polarized Caco-2 monolayers. Furthermore, there were no changes in paracellular permeability to a $3 \mathrm{kDa}$ dextran probe $(P=0.13)$ and transepithelial electrical resistance (TER) remained above $250 \Omega \times \mathrm{cm}_{2}(P=0.39$; Table 1$)$ which is indicative of intact tight epithelial junctions in this cell type. This supports our previous observations that a transcellular mechanism is responsible for C. jejunimediated E. coli translocation. Similarly, a recent study showed that the enteric pathogen, Yersinia pseudotuberculosis, also induces translocation of exogenous particles across both Caco-2 monolayers and human intestinal epithelium by an as yet uncharacterized transcellular mechanism [29]. This novel transcellular mechanism of barrier dysfunction contrasts with the paracellular mechanism described for many enteric pathogens such as enterohemorrhagic E. coli and Salmonella, which increase intestinal permeability by disrupting epithelial tight junctions [30].

C. jejuni-treated monolayers displayed an overall reduction in absorptive epithelial enzymatic activities (Table 2). Specifically, alkaline phosphatase was decreased by $\sim 9.2 \%(P=0.01)$, lactase was decreased by $\sim 8.3 \%(P=0.001)$, and sucrase was decreased by $28 \%$ $(P=0.046)$. This is consistent with the previously reported decrease in intestinal sucrase-isomaltase

Table 1 E. coli translocation and internalization, and epithelial permeability in Caco-2 monolayers treated with E. coli C25 alone (control) versus monolayers inoculated with E. coli $\mathrm{C} 25$ and $C$. jejuni 81-176

\begin{tabular}{lccc}
\hline & Control & C. jejuni & $\boldsymbol{P}$ \\
\hline Translocated E. coli $\left(\log _{10} \mathrm{CFU} / \mathrm{mL}\right)$ & $0.19 \pm 0.19$ & $1.42 \pm 0.296$ & 0.023 \\
Internalized E. coli $\left(\log _{10} \mathrm{CFU} / \mathrm{mL}\right)$ & $3.66 \pm 0.36$ & $4.97 \pm 0.07$ & 0.023 \\
Initial TER $\left(\Omega \times \mathrm{cm}^{2}\right)$ & $298 \pm 4.2$ & $311 \pm 9.4$ & 0.28 \\
Final TER $\left(\Omega \times \mathrm{cm}^{2}\right)$ & $354 \pm 19.7$ & $335 \pm 2.1$ & 0.39 \\
Permeability $(\%$ apical dextran & $0.95 \pm 0.02$ & $1.01 \pm 0.02$ & 0.13 \\
recovered) & & & \\
\hline
\end{tabular}

Data are expressed as mean \pm SEM, $n=3$ independent experiments. 
Table 2 Intestinal epithelial enzyme activities for Caco-2 monolayers treated with E. coli C25 alone (control) verses monolayer treated with E. coli C25 and C. jejuni 81-176

\begin{tabular}{lccc}
\hline & $\begin{array}{c}\text { Control } \\
\text { (units/g protein) }\end{array}$ & $\begin{array}{c}\text { C. jejuni } \\
\text { (units/g protein) }\end{array}$ & $\boldsymbol{P}$ \\
\hline Alkaline Phosphatase & $67.6 \pm 1.3$ & $61.4 \pm 0.5$ & 0.01 \\
Lactase & $217.6 \pm 1.8$ & $199.6 \pm 1.3$ & 0.001 \\
Sucrase & $77.5 \pm 4.5$ & $55.8 \pm 6.1$ & 0.046 \\
\hline
\end{tabular}

Data are expressed as mean \pm SEM, $n=3$ independent experiments.

activity that occurs in the Caco-2 monolayers upon differentiation to M-like cells [25]. Notably, intestinal alkaline phosphatase has been recently show to detoxify lipopolysaccharide (a component of Gram negative bacteria cell walls) and prevent bacterial translocation [31], suggesting that reduced alkaline phosphatase activity may be one of the factors contributing to transcytosis of E. coli in C. jejuni-treated monolayers. Also, transient lactose malabsorption has been observed following campylobacteriosis [32], this may warrant further investigation.

Microscopic analysis revelled an increase $(P=0.002)$ in the number of cells that stained positive for galectin9 in C. jejuni-treated $(11.6 \pm 0.5 \%)$ versus control $(2.9 \pm$ $0.5 \%)$ monolayers. Furthermore, in C. jejuni-treated monolayers, $E$. coli were primarily associated with Caco2 cells displaying characteristics of M-like cells, namely those that displayed reduced apical binding of UEA-1 lectin and increased expression of galectin-9 (Figure 1). In contrast, control monolayers exhibited very few galectin-9 positive cells or associated E. coli. Caco- 2 monolayers were sectioned using confocal laser analysis, and for each section in the z-axis, E. coli were coloured according to depth from yellow (extracellular) to blue (intracellular). In C. jejuni-treated monolayers, intracellular E. coli were associated with UEA-1-negative Caco2 cells (Figure 2). The few extracellular bacteria were associated with UEA-1-positive Caco-2 cells (i.e., absorptive enterocytes). In control monolayers, only the occasional extracellular E. coli was observed (not shown). While cautious interpretation of data resulting from $M$ cell staining is necessary owing to lack of a universally accepted human $M$ cell marker, it appears that our collective data indicate that $C$. jejuni converts Caco2 cells into cells displaying biochemical, functional, and histological features of $M$ cells. In a similar manner, the differentiation of M-like cells has been shown to occur in response to bacterial infection and inflammation [20,22,33-35].

An important observation is that the epithelial responses appear to be specific to $C$. jejuni, since $E$. coli alone does not cause appreciable formation of M-like cells within Caco-2 monolayers. Although we are unsure of the exact mechanism, current studies have demonstrated that metabolic stress increases internalization and translocation of non-pathogenic E.coli across the intestinal epithelium [36,37]. We and other have previously noted swollen mitochondria (indicative of metabolic stress) in cell culture and animal models of campylobacteriosis [38-42]. It appears that mucosal pathogens often target the mitochondria as part of their common pathogenic strategy [43]. Thus, one possible explanation for our observations could be that increased $\mathrm{M}$ cell formation and subsequent transcytosis occur as a consequence of metabolic stress associated with $C$. jejuni pathogenesis.

Controversy continues on whether $\mathrm{M}$ cells arise from a distinct pre-determined lineage of crypt stem cells, or whether absorptive enterocytes exhibit phenotypic plasticity and can be "converted" to M cells $[21,24]$. Since immortalized Caco- 2 cells are not terminally differentiated but rather resemble crypt stem cells $[44,45]$, they are thus theoretically able to differentiate into different epithelial lineages such as absorptive enterocytes or M-like cells.
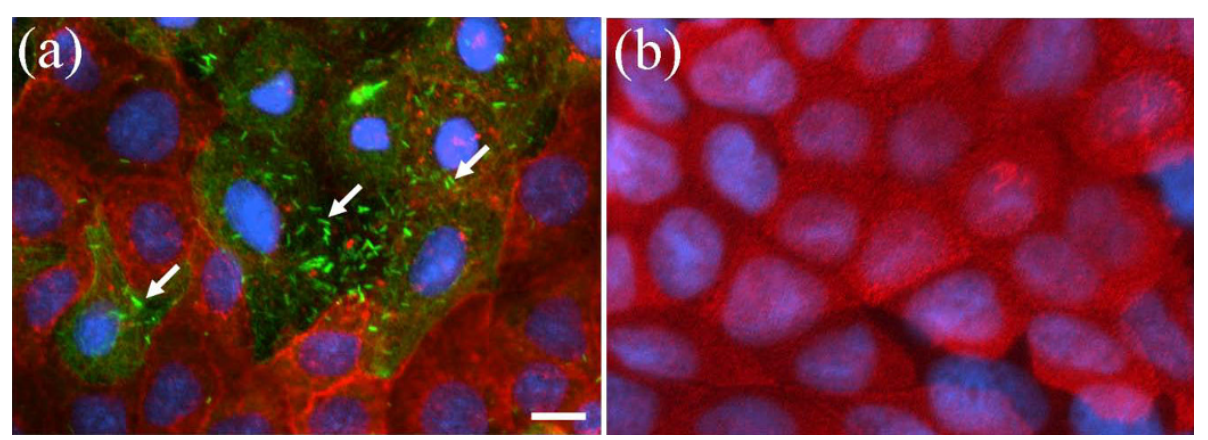

Figure 1 Representative epifluorescent micrographs of Caco-2 monolayers stained with the absorptive enterocyte marker Ulex europaeus agglutinin-1 (red), the M-like cell specific marker galectin-9 (green diffuse cellular staining), and Hoechst nuclear stain (blue). (a) Monolayers treated with GFP Escherichia coli C25 (arrows) and C. jejuni 81-176. (b) Monolayers treated with only GFP E. coli C25 (control). Bar $=2 \mu \mathrm{m}$. 


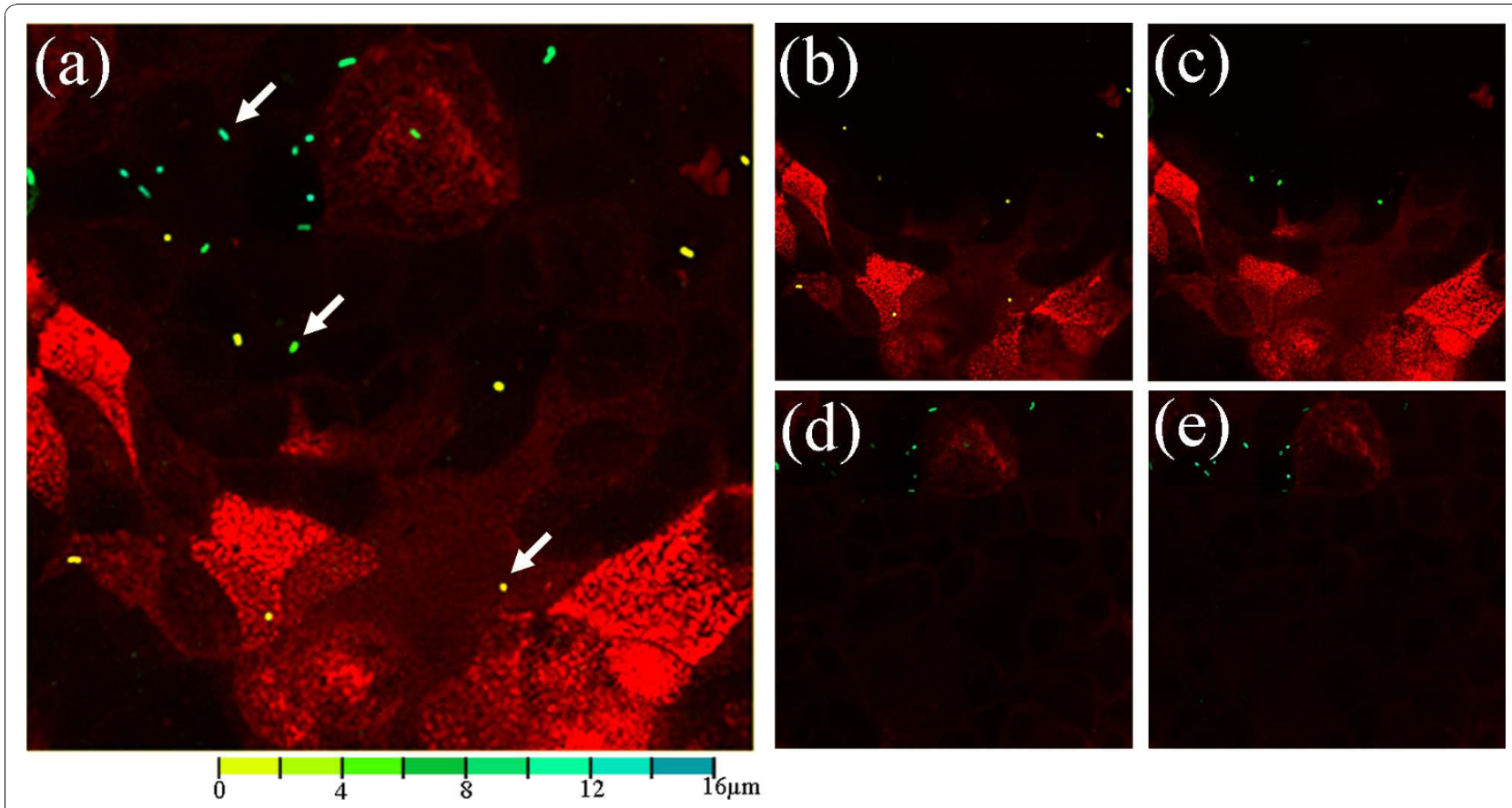

Figure 2 Confocal laser sections of Caco-2 monolayers treated with C. jejuni 81-176 plus non-invasive GFP Escherichia coli C25 (arrows) and stained with the absorptive enterocyte marker Ulex europaeus agglutinin-1 (red). E. coli are color-coded according to their respective depth within the monolayer from extracellular (yellow) to intracellular (blue). (a) Merge of all confocal laser sections. (b-e) Representative confocal laser sections starting from the apical surface of the monolayer (E. coli color-coded yellow) to the basolateral surface of the monolayer (E. coli color-coded blue).

The rapid timing with which E. coli translocation occurred following $C$. jejuni infection (i.e., $6 \mathrm{~h}$ ), suggests that $C$. jejuni may target progenitor $\mathrm{M}$-like cells within the monolayer rather than convert fully differentiated epithelial cells into M-like cells. Future studies are necessary to understand the precise mechanisms by which M-like cells originate in response to $C$. jejuni.

\section{Conclusion}

Our data indicates that $C$. jejuni may utilize M cells to promote transcytosis of non-invasive bacteria across the intact intestinal epithelial barrier. Based on previous clinical observations, microscopic aphtoid lesions of the FAE (i.e., regions containing $M$ cells) appear to be the initial site of inflammation in patients with Crohn's disease [46]. Notably, a recent study of patients with Crohn's disease reported increased transmucosal uptake of non-pathogenic $E$. coli across the ileal FAE despite unaltered epithelial permeability [47], suggesting that trancellular defects in the FAE contribute to the pathophysiology of IBD. M cells may play an important role in IBD pathogenesis by increasing transcytosis of commensal bacteria to the inductive sites of mucosal immune responses [48]. Campylobacter enteritis has been recently identified as a risk factor for IBD $[16,17]$. By increasing $M$ cell-mediated trancytosis of non- invasive bacteria, $C$. jejuni may contribute to the activation of $\mathrm{T}$ lymphocyte-mediated immune responses against commensal bacteria commonly observed in IBD patients. Future studies will be required to determine whether $C$. jejuni-induced $M$ cell-mediated transcytosis of commensal bacteria occurs in vivo and whether this causes aberrant $\mathrm{T}$ lymphocyte-mediated immune responses.

\section{Methods}

\section{Bacteria and growth conditions}

C. jejuni 81-176, a reference clinical strain [49], was used throughout this study. For microscopy studies, Escherichia coli C25 transformed with GFP-expressing plasmid pMEK91 was used [50]. Inoculum was prepared by growing $C$. jejuni or $E$. coli for 14-16 hours in Columbia broth $\left(37^{\circ} \mathrm{C}, 100 \mathrm{rpm}\right.$, Difco, Detroit, MI) in microaerobic $\left(10 \% \mathrm{CO}_{2}, 3 \% \mathrm{H}_{2}, 5 \% \mathrm{O}_{2}\right.$, balance $\left.\mathrm{N}_{2}\right)$ or aerobic atmosphere, respectively.

\section{Caco-2 M-like cell model}

Caco-2 cells (American Type Culture Collection, Manassas, VA) were grown in Advanced Dulbecco's minimal essential medium (DMEM; Gibco Invitrogen Inc., Burlington, $\mathrm{ON})$ supplemented with $10 \%(\mathrm{v} / \mathrm{v})$ fetal bovine serum, $200 \mathrm{mM}$ L-glutamine, $100 \mathrm{U} / \mathrm{mL}$ penicillin, 
$100 \mu \mathrm{g} / \mathrm{mL}$ streptomycin, $80 \mu \mathrm{g} / \mathrm{mL}$ tylosin (all from Sigma-Aldrich, Oakville, ON), and incubated at $37^{\circ} \mathrm{C}$ and $5 \% \mathrm{CO}_{2}$. For E. coli translocation and internalization, epithelial permeability, and enzyme activity assays, cells were seeded onto Transwell filters $(3 \mu \mathrm{m}$ pore size, $1.13 \mathrm{~cm}^{2}$; Costar Corning Inc., Corning, NY) at $1.5 \times$ $10^{5}$ cells per filter and grown for 21 days. For microscopy, cells were seeded into chamber slides (Nalgene Nunc International, Naperville, IL) at $3 \times 10^{5}$ cells per well.

\section{E. coli translocation and internalization assays}

E. coli translocation and internalization were determined as previously described [18]. Briefly, transwell-grown monolayers were washed with Hank's buffered saline (HBS; Gibco) and antibiotic-free DMEM was added to the apical and basal compartments. E. coli inoculum was added to the apical compartment of all monolayers to achieve a multiplicity of infection (MOI) of $100 \mathrm{CFU}$ per enterocyte. Monolayers were then divided in to two groups and half were inoculated with $C$. jejuni at a MOI of 100 , whereas the other half received an equivalent volume of sterile broth (control treatment).

Following incubation, E. coli recovered in the basal compartment (indicating translocation) were enumerated by spreading serial dilutions onto MacConkey agar, incubating the cultures aerobically at $37^{\circ} \mathrm{C}$, and enumerating at the dilution yielding 30-300 colony forming units (CFU) per culture. A preliminary experiment confirmed that $6 \mathrm{~h}$ was the minimum optimal incubation time for assessing E. coli translocation. To assess $E$. coli internalization, treated monolayers were washed with HBS and incubated for 1 hour with DMEM containing gentamicin (250 $\mu \mathrm{g} / \mathrm{mL}$; Sigma). Monolayers were then washed, lysed with $0.1 \%$ Triton $\mathrm{X}-100$ in PBS $(500 \mu \mathrm{L})$, and viable bacteria were enumerated as described above. A preliminary experiment confirmed that $E$. coli were killed by the gentamicin treatment. Transepithelial electrical resistance was monitored at the beginning and end of each experiment with an electrovoltohmeter (World Precision Instruments, Sarasota, FL). Only monolayers with an initial TER $>225 \Omega \times \mathrm{cm}^{2}$ were used.

\section{Epithelial permeability assay}

Transwell-grown monolayers were inoculated with $E$. coli $\pm C$. jejuni as described above, and monolayers were washed with Ringer's buffer 6 hours after inoculation. A $3 \mathrm{kDa}$ FITC-dextran probe (100 mM in Ringer's buffer; $500 \mu \mathrm{L}$ per well; Molecular Probes, Eugene, OR) was added to the apical compartment and $1 \mathrm{~mL}$ of Ringer's buffer was added to the basal compartment, and the monolayers were incubated for 3 hours at $37^{\circ} \mathrm{C}$ as described previously [18]. Samples $(200 \mu \mathrm{l})$ were collected from the basal compartment and the absorbance at $485 \mathrm{~nm}$ was measured. Data were expressed as \% apical dextran recovered in the basal compartment.

\section{Epithelial enzyme activity assays}

Transwell-grown monolayers were inoculated with E. coli $\pm C$. jejuni as described above. After 6 hours, monolayers were washed with PBS and lysed with $0.2 \%$ Triton X-100 in PBS $(500 \mu \mathrm{L}$ per well) on ice for 20 minutes. Cell lysates were clarified by centrifugation (2 minutes, 16,000 (g). Total protein concentration of the lysates was determined using the Bradford protein assay (Bio-Rad, Mississauga, ON) and were calculated by interpolation of a standard curve generated with known concentrations of bovine serum albumin (BSA).

Alkaline phosphatase activity was measured by hydrolysis of p-nitrophenyl phosphate (pNPP; Sigma) reagent according to the manufacturer's instructions. Briefly, cell lysates $(20 \mu \mathrm{L})$ were incubated for 30 minutes at $37^{\circ} \mathrm{C}$ with pNPP reagent $(500 \mu \mathrm{L})$. The reaction was stopped with $2 \mathrm{M} \mathrm{NaOH}(150 \mu \mathrm{L})$ and measured spectrophotometrically at $\mathrm{A}_{410} \mathrm{~nm}$. Enzyme activity was calculated by interpolation of a standard curve generated with alkaline phophatase of defined activity. Enzyme activity was expressed as units/g protein, where 1 unit is defined as the amount of enzyme that hydrolyzed $1 \mu \mathrm{M}$ of pNPP per minute at $37^{\circ} \mathrm{C}$.

Sucrase and lactase activities were measured according to the method of Dahlqvist [51]. In brief, cell lysates $(50 \mu \mathrm{L})$ were incubated with sucrose or lactose $(50 \mu \mathrm{L}$ of $100 \mathrm{mM}$ disaccharide in $0.1 \mathrm{M}$ maleate buffer, $\mathrm{pH}$ 6; Sigma) in each of two separate tubes. One set of tubes, used to measure background endogenous glucose in the sample, was heated at $95^{\circ} \mathrm{C}$ for 2 minutes. The second set of tubes was placed in a $37^{\circ} \mathrm{C}$ water bath for 4 hours followed by $95^{\circ} \mathrm{C}$ for 2 minutes. Glucose oxidase reagent (200 $\mu \mathrm{L}$; Sigma) was added to each tube and then incubated at $37^{\circ} \mathrm{C}$ for 1 hour. A coloured product of $\mathrm{O}$-dianisidine, which is produced based on the amount of glucose liberated in the samples, was measured spectrophotometrically at $\mathrm{A}_{420} \mathrm{~nm}$. Glucose in each lysate was calculated by interpolation of a glucose standard curve. Enzyme activity was expressed as units/g protein, where 1 unit is defined as the amount of enzyme that liberated $1 \mu \mathrm{M}$ of glucose in 1 hour.

\section{$M$ cell staining, epifluorescent and confocal microscopy}

Confluent Caco-2 monolayers grown on chamber slides were inoculated with $E$. coli $\pm C$. jejuni as described above. Caco-2 monolayers were washed with PBS 6 hours after inoculation, and fixed in paraformaldehyde (2\%). Galectin-9 staining was performed as previously described [27]. Briefly, slides were washed with PBS, incubated with glycine (1\% in PBS) for 15 minutes, and washed with PBS. Cells were permeabilized for 
10 minutes with Triton X-100 (0.5\% in PBS), blocked with BSA (2\% in PBS), incubated with goat anti-human Galectin-9 antibodies (1\% in PBS; R\&D Systems Inc., Minneapolis, $\mathrm{MN}$ ) followed by Alexa-488 conjugated anti-goat IgG ( $0.2 \%$ in PBS; Molecular Probes). Monolayers were then washed with PBS and incubated for 30 minutes with TRITC-conjugated UEA- $1(5 \mu \mathrm{g} / \mathrm{mL}$ in PBS; Sigma). After washing with PBS, slides were stained for 15 minutes with Hoechst nuclear stain $(1 \mu \mathrm{M}$; Molecular Probes) and washed with PBS. Coverslips were mounted with Aqua-Mount (Lerner Laboratories, Pittsburgh, PA) according to the manufacturer's instructions. Slides were examined by epifluorescent microscopy using appropriate filters. Slides were blinded by taping the labels, and a grid was drawn on the back of each slide. The same section of the grid was examined by epifluorescent microscopy and scored for total number of cells and number of $\mathrm{M}$ cells (i.e., galectin-9 positive, UEA negative). Confocal optical sectioning was carried out using an inverted microscope equipped with a confocal laser scanning imaging system (Leica Microsystems, Wetzler, Germany).

\section{Statistical analysis}

Each assay was conducted at least three times on separate occasions. For each replicate, observations were conducted at least in triplicate, and mean values were used for analysis. Data are expressed as means \pm SEM. Unpaired Student's t-test were used to compare means of control versus C. jejuni-treated samples (GraphPad InStat software, GraphPad Software Inc., San Diego, CA). $P \leq 0.05$ was considered significant.

\section{Acknowledgements}

We thank Dr. ME Konkel, Washington State University, for the gift of pMEK91. This work was supported by an AAFC Peer Review Grant to GDI and LKT.

\section{Authors' contributions \\ LKT participated in the design of the study, performed experiments, conducted data analysis, and drafted the manuscript. FL conducted confocal microscopy and image analysis. GDI participated in the design of the study and edited the manuscript. All authors read and approved the final manuscript.}

\section{Competing interests}

The authors declare that they have no competing interests.

Received: 15 September 2010 Accepted: 1 November 2010 Published: 1 November 2010

\section{References}

1. Maul J, Duchmann R: Can loss of immune tolerance cause IBD? Inflamm Bowel Dis 2008, 14(Suppl 2):S115-116.

2. Su L, Shen L, Clayburgh DR, Nalle SC, Sullivan EA, Meddings JB, Abraham C, Turner JR: Targeted epithelial tight junction dysfunction causes immune activation and contributes to development of experimental colitis. Gastroenterology 2009, 136:551-563.
3. Laukoetter MG, Nava $P$, Nusrat $A$ : Role of the intestinal barrier in inflammatory bowel disease. World J Gastroenterol 2008, 14(3):401-407.

4. Gardiner KR, Halliday MI, Barclay GR, Milne L, Brown D, Stephens S, Maxwell RJ, Rowlands BJ: Significance of systemic endotoxaemia in inflammatory bowel disease. Gut 1995, 36:897-901.

5. Gutierrez A, Frances R, Amoros A, Zapater P, Garmendia M, Ndongo M, Cano R, Jover R, Such J, Perez-Mateo M: Cytokine association with bacterial DNA in serum of patients with inflammatory bowel disease. Inflamm Bowel Dis 2009, 15:508-514.

6. Duchmann R, Kaiser I, Hermann E, Mayet W, Ewe K, Meyer zum Buschenfelde $\mathrm{KH}$ : Tolerance exists towards resident intestinal flora but is broken in active inflammatory bowel disease (IBD). Clin Exp Immunol 1995, 102:448-455.

7. Adams RJ, Heazlewood SP, Gilshenan KS, O'Brien M, McGuckin MA, Florin $\mathrm{TH}$ : IgG antibodies against common gut bacteria are more diagnostic for Crohn's disease than lgG against mannan or flagellin. Am J Gastroenterol 2008, 103:386-396.

8. Macpherson A, Khoo UY, Forgacs I, Philpott-Howard J, Bjarnason I: Mucosal antibodies in inflammatory bowel disease are directed against intestinal bacteria. Gut 1996, 38:365-375.

9. Soderholm JD, Streutker C, Yang PC, Paterson C, Singh PK, McKay DM, Sherman PM, Croitoru K, Perdue MH: Increased epithelial uptake of protein antigens in the ileum of Crohn's disease mediated by tumour necrosis factor alpha. Gut 2004, 53:1817-1824.

10. Schurmann G, Bruwer M, Klotz A, Schmid KW, Senninger N, Zimmer KP: Transepithelial transport processes at the intestinal mucosa in inflammatory bowel disease. Int J Colorectal Dis 1999, 14:41-46.

11. Porras M, Martin MT, Yang PC, Jury J, Perdue MH, Vergara P: Correlation between cyclical epithelial barrier dysfunction and bacterial translocation in the relapses of intestinal inflammation. Inflamm Bowel Dis 2006, 12:843-852.

12. Halfvarson J, Jess T, Magnuson A, Montgomery SM, Orholm M, Tysk C, Binder $V$, Jarnerot $G$ : Environmental factors in inflammatory bowel disease: a co-twin control study of a Swedish-Danish twin population. Inflamm Bowel Dis 2006, 12:925-933.

13. Mylonaki M, Langmead L, Pantes A, Johnson F, Rampton DS: Enteric infection in relapse of inflammatory bowel disease: importance of microbiological examination of stool. Eur J Gastroenterol Hepatol 2004, 16:775-778.

14. Stallmach A, Carstens $O$ : Role of infections in the manifestation or reactivation of inflammatory bowel diseases. Inflamm Bowel Dis 2002, 8:213-218.

15. Ruigomez A, Garcia Rodriguez LA, Panes J: Risk of irritable bowel syndrome after an episode of bacterial gastroenteritis in general practice: influence of comorbidities. Clin Gastroenterol Hepatol 2007, 5:465-469

16. Garcia Rodriguez $L A$, Ruigomez A, Panes J: Acute gastroenteritis is followed by an increased risk of inflammatory bowel disease. Gastroenterology 2006, 130:1588-1594.

17. Gradel KO, Nielsen HL, Schonheyder HC, Ejlertsen T, Kristensen B, Nielsen H: Increased short- and long-term risk of inflammatory bowel disease after Salmonella or Campylobacter gastroenteritis. Gastroenterology 2009, 137:495-501.

18. Kalischuk LD, Inglis GD, Buret AG: Campylobacter jejuni induces transcellular translocation of commensal bacteria via lipid rafts. Gut Pathog 2009, 1:2

19. Kalischuk LD, Buret AG: A role for Campylobacter jejuni-induced enteritis in inflammatory bowel disease? Am J Physiol Gastrointest Liver Physiol 2009, 298:G1-9.

20. Jang MH, Kweon MN, Iwatani K, Yamamoto M, Terahara K, Sasakawa C, Suzuki T, Nochi T, Yokota Y, Rennert PD, et al: Intestinal villous M cells: an antigen entry site in the mucosal epithelium. Proc Natl Acad Sci USA 2004, 101:6110-6115.

21. Kerneis $S$, Pringault E: Plasticity of the gastrointestinal epithelium: the $M$ cell paradigm and opportunism of pathogenic microorganisms. Semin Immunol 1999, 11:205-215.

22. Borghesi C, Taussig MJ, Nicoletti C: Rapid appearance of M cells after microbial challenge is restricted at the periphery of the follicleassociated epithelium of Peyer's patch. Lab Invest 1999, 79:1393-1401. 
23. Meynell HM, Thomas NW, James PS, Holland J, Taussig MJ, Nicoletti C: Upregulation of microsphere transport across the follicle-associated epithelium of Peyer's patch by exposure to Streptococcus pneumoniae R36a. Faseb J 1999, 13:611-619.

24. Gebert A, Steinmetz I, Fassbender S, Wendlandt KH: Antigen transport into Peyer's patches: increased uptake by constant numbers of $M$ cells. Am J Pathol 2004, 164:65-72.

25. Kerneis S, Bogdanova A, Kraehenbuhl JP, Pringault E: Conversion by Peyer's patch lymphocytes of human enterocytes into $\mathrm{M}$ cells that transport bacteria. Science 1997, 277:949-952

26. Blanco LP, DiRita VJ: Bacterial-associated cholera toxin and GM1 binding are required for transcytosis of classical biotype Vibrio cholerae through an in vitro M cell model system. Cell Microbiol 2006, 8:982-998.

27. Pielage JF, Cichon C, Greune L, Hirashima M, Kucharzik T, Schmidt MA: Reversible differentiation of Caco-2 cells reveals galectin- 9 as a surface marker molecule for human follicle-associated epithelia and $\mathrm{M}$ cell-like cells. Int J Biochem Cell Biol 2007, 39:1886-1901.

28. Man AL, Lodi F, Bertelli E, Regoli M, Pin C, Mulholland F, Satoskar AR, Taussig MJ, Nicoletti C: Macrophage migration inhibitory factor plays a role in the regulation of microfold $(\mathrm{M})$ cell-mediated transport in the gut. I Immunol 2008, 181:5673-5680.

29. Ragnarsson EG, Schoultz I, Gullberg E, Carlsson AH, Tafazoli F, Lerm M, Magnusson KE, Soderholm JD, Artursson P: Yersinia pseudotuberculosis induces transcytosis of nanoparticles across human intestinal villus epithelium via invasin-dependent macropinocytosis. Lab Invest 2008, 88:1215-1226.

30. Sears CL: Molecular physiology and pathophysiology of tight junctions $\mathrm{V}$. assault of the tight junction by enteric pathogens. Am J Physiol Gastrointest Liver Physiol 2000, 279:G1129-1134.

31. Goldberg RF, Austen WG Jr, Zhang X, Munene G, Mostafa G, Biswas S, McCormack M, Eberlin KR, Nguyen JT, Tatlidede HS, et al: Intestinal alkaline phosphatase is a gut mucosal defense factor maintained by enteral nutrition. Proc Natl Acad Sci USA 2008, 105:3551-3556.

32. Lazaro A, Selles H, Calvo MA, Olivares JL, Castillo J, Gomez-Lus F, Bueno M: [Digestive complications of Campylobacter enteritis]. An Esp Pediatr 1985, 22:275-279.

33. Lugering A, Floer M, Lugering N, Cichon C, Schmidt MA, Domschke W, Kucharzik T: Characterization of $\mathrm{M}$ cell formation and associated mononuclear cells during indomethacin-induced intestinal inflammation. Clin Exp Immunol 2004, 136:232-238.

34. Cuvelier CA, Quatacker J, Mielants H, De Vos M, Veys E, Roels HJ: M-cells are damaged and increased in number in inflamed human ileal mucosa. Histopathology 1994, 24:417-426.

35. Rhee KJ, Sethupathi P, Driks A, Lanning DK, Knight KL: Role of commensal bacteria in development of gut-associated lymphoid tissues and preimmune antibody repertoire. J Immunol 2004, 172:1118-1124.

36. Nazli A, Yang PC, Jury J, Howe K, Watson JL, Soderholm JD, Sherman PM, Perdue MH, McKay DM: Epithelia under metabolic stress perceive commensal bacteria as a threat. Am J Pathol 2004, 164:947-957.

37. Lewis K, Caldwell J, Phan V, Prescott D, Nazli A, Wang A, Soderholm JD, Perdue MH, Sherman PM, McKay DM: Decreased epithelial barrier function evoked by exposure to metabolic stress and nonpathogenic $E$. coli is enhanced by TNF-alpha. Am J Physiol Gastrointest Liver Physiol 2008, 294:G669-678.

38. De Melo MA, Gabbiani G, Pechere JC: Cellular events and intracellular survival of Campylobacter jejuni during infection of HEp-2 cells. Infect Immun 1989, 57:2214-2222.

39. Humphrey CD, Montag DM, Pittman FE: Morphologic observations of experimental Campylobacter jejuni infection in the hamster intestinal tract. Am J Pathol 1986, 122:152-159.

40. Kalischuk LD, Inglis GD, Buret AG: Strain-dependent induction of epithelial cell oncosis by Campylobacter jejuni is correlated with invasion ability and is independent of cytolethal distending toxin. Microbiology 2007, 153:2952-2963.

41. Gao JX, Ma BL, Xie YL, Huang DS: Electron microscopic appearance of the chronic Campylobacter jejuni enteritis of mice. Chin Med J (Engl) 1991, 104:1005-1010.

42. Newell DG, Pearson A: The invasion of epithelial cell lines and the intestinal epithelium of infant mice by Campylobacter jejuni/coli. J Diarrhoeal Dis Res 1984, 2:19-26.
43. Blanke SR: Micro-managing the executioner: pathogen targeting of mitochondria. Trends Microbiol 2005, 13:64-71.

44. Engle MJ, Goetz GS, Alpers DH: Caco-2 cells express a combination of colonocyte and enterocyte phenotypes. J Cell Physiol 1998, 174:362-369.

45. Owen RL: Mid-life crisis for M cells. Gut 1998, 42:11-12.

46. Fujimura Y, Kamoi R, lida M: Pathogenesis of aphthoid ulcers in Crohn's disease: correlative findings by magnifying colonoscopy, electron microscopy, and immunohistochemistry. Gut 1996, 38:724-732.

47. Keita AV, Salim SY, Jiang T, Yang PC, Franzen L, Soderkvist $P$, Magnusson KE, Soderholm JD: Increased uptake of non-pathogenic $E$. coli via the follicleassociated epithelium in longstanding ileal Crohn's disease. J Pathol 2008, 215:135-144

48. Gullberg E, Soderholm JD: Peyer's patches and M cells as potential sites of the inflammatory onset in Crohn's disease. Ann N Y Acad Sci 2006, 1072:218-232.

49. Korlath JA, Osterholm MT, Judy LA, Forfang JC, Robinson RA: A pointsource outbreak of campylobacteriosis associated with consumption of raw milk. J Infect Dis 1985, 152:592-596.

50. Mixter PF, Klena JD, Flom GA, Siegesmund AM, Konkel ME: In vivo tracking of Campylobacter jejuni by using a novel recombinant expressing green fluorescent protein. Appl Environ Microbiol 2003, 69:2864-2874.

51. Dahlqvist A: Method for assay of intestinal disaccharidases. Anal Biochem 1964, 7:18-25

doi:10.1186/1757-4749-2-14

Cite this article as: Kalischuk et al:: Campylobacter jejuni induces transcytosis of commensal bacteria across the intestinal epithelium through M-like cells. Gut Pathogens 2010 2:14.

\section{Submit your next manuscript to BioMed Central and take full advantage of:}

- Convenient online submission

- Thorough peer review

- No space constraints or color figure charges

- Immediate publication on acceptance

- Inclusion in PubMed, CAS, Scopus and Google Scholar

- Research which is freely available for redistribution

Submit your manuscript at www.biomedcentral.com/submit
C Biomed Central 